GEOGRAFIE • ROK 2013 • ČÍSLO 3 • ROČNÍK 118

JAN BLAHU゚T, JAN KLIMEŠ, ZUZANA VǍ̌ILOVÁ

\title{
QUANTITATIVE ROCKFALL HAZARD AND RISK ANALYSIS IN SELECTED MUNICIPALITIES OF THE ČESKÉ ŠVÝCARSKO NATIONAL PARK, NORTHWESTERN CZECHIA
}

\begin{abstract}
BLAHU゚T, J., KLIMEŠ, J., VǍ̌ILOVÁ, Z. (2013): Quantitative rockfall hazard and risk analysis in selected municipalities of the Ceské Švýcarsko National Park, northwestern Czechia. Geografie, 118, No. 3, pp. 205-220. - Quantitative rockfall hazard and specific risk assessment of the selected municipalities within the České Švýcarsko National Park was performed using two rockfall hazard analysis modelling codes. CONEFALL and RockFall Analyst codes were used to delimit rockfall hazard regions. Specific risk to buildings was consequently assessed using results from the hazard analysis and literature-derived vulnerability values. Results of hazard and risk assessments for two nearby municipalities were compared and evaluated. Both models provide similar rockfall hazard values in areas characterized with relatively steep $\left(36^{\circ}-50^{\circ}\right)$, convex and short slopes (up to $200 \mathrm{~m}$ ). Whereas in regions with less steep $\left(20^{\circ}-35^{\circ}\right)$, concave and longer slopes (about $350 \mathrm{~m}$ ) the predicted rockfall hazard differs considerably. We argue that the results of the RockFall Analyst are more reliable due to complex input data and modelling approach which closely resembles the natural process of falling rocks on forested slopes. Differences in hazard assessment are further reflected in assigning risk values to exposed buildings, where CONEFALL is more conservative.

KEY WORDS: rockfall hazard and risk - quantitative risk - Cretaceous sandstones - CONEFALL - Rockfall Analyst - České Švýcarsko National Park.
\end{abstract}

\section{Introduction}

Rockfalls represent fast-moving mass movements with high range of volume of involved rock mass ranging from few cubic centimeters to thousand of cubic meters (Katz, Reichenbach, Guzzetti 2011; Klimeš, Vilímek, Omelka 2009). Due to their high velocities (up to tens of meters per second), even low magnitude (i.e. small volume) events may be highly destructive with the potential to cause fatalities.

Variety of approaches has been used to assess rockfall hazard and risk on regional scale using GIS technology forming two main groups. The first one represents approach attempting to define an objective way to determine rockfall detachment areas and falling block size. To achieve this, following characteristics are being obtained and mapped on regional scale - slope dip, fracture spacing, geometric characteristics of the discontinuity sets and slope. Here belong early works combining series of factor maps (e.g. slope dip, discontinuity measurements) used for hazard mapping in structurally homogenous regions (Wagner, Oliver, Leite 1988). Increasing availability of accurate and detailed 
Digital Elevation Models (DEMs) was used for more complex rockfall hazard assessment models. They include deterministic approach to establish fracture densities and block geometry as continuous parameter into GIS suggested by Sturzenegger et al. (2007).

Second approach works with assumption that the location, size and shape of falling boulder are known. This may be entirely theoretical assumption or based on historical event description or detailed field research. This approach focuses on accurate description of falling block trajectories while travelling down the slope. It requires determining position of the rock block on the slope, its size, shape, volume, slope dip and characteristics of the boulder/slope surface interaction affecting its movement. Among those belong slope dip, surface characteristics and presence of obstacles including vegetation (Guzzetti et al. 2002; Bigot, Dorren, Berger 2009). Modelling results strongly depend especially on the DEM accuracy affecting spatial distribution of rockfall frequencies and therefore also hazard and risk assessment (Lan et al. 2010). Use of other than detailed and high precision LiDAR-derived DEMs may lead to partly misleading modelling results. Rockfall trajectory is described in $2 \mathrm{D}$ or $3 \mathrm{D}$ using fall height and speed as main characteristics. Moreover, geotechnical characteristics of the falling boulders may be required to describe its behavior (e.g. potential fragmentation) during the fall. Position of centre of gravity, uniaxial compressive strength and degree of weathering are being used for this purpose (Almeida, Kullberg 2011). Models calculate boulder speed, height over terrain, energy and number of passes for each spatial element of the map. Combination of both approaches is used for example in Almeida and Kullberg (2011) where multivariate statistics are used to evaluate fall probability and basic fall characteristics. Fall behavior is then modeled by automata-type algorithm using set of transition rules and probability distribution function to determine boulder behavior. Most of the above mentioned methods lack to consider stone shape, its fragmentation and interaction with barriers during the fall. Fragmentation of the rock block may cause overestimation of the kinetic energy by the model (Lan et al. 2010). Shape of the falling rock and trees considered as barriers for falling stones are incorporated into the Rockyfor.Net and Rockyfor.3D software (Bigot, Dorren, Berger 2009).

Sturzenegger et al. (2007) are suggesting simple way of using results of deterministic mapping of rock block size and geometry of potential rockfall for mitigation purposes. Its result allows mapping of areas with high probability of rockfalls with specific size and geometry. Simple rating system defining threshold values of rock block size is suggested to identify areas with high hazard potential of rockfalls. Unfortunately, no further details about this system, including threshold values are given. Almeida and Kullberg (2011) are using 1,000 simulations for each boulder to produce rockfall areas classified by rockfall frequency per pixel. Moreover, they rank source boulders in terms of rockfall initiation probability (static behavior), disintegration probability during the fall (dynamic behavior) and probability that fall of specific boulder will mobilize surrounding boulders. These characteristics are combined with run-out characteristics among which proximity of the fall boulders to the nearest houses is considered, to prepare expert hazard and risk rating of each boulder location. Lan et al. (2010) overlays rockfall frequencies, height and 
kinetic energy raster calculated with Rockfall Analyst to obtain hazard classes along the railway track. Vulnerability of the elements at risk to the rockfalls needs to be described in order to perform risk assessment. It is quite difficult mainly due to the lack of historical data about caused damages which may be related to a specific rockfall event and highly variable and partly unknown (at least in the case of the regional analysis) technical properties of the exposed elements at risk. Despite of that, historical records about damages caused by rockfalls may be used to evaluate rockfall vulnerability (e.g. Cardinali et al. 2002). A quantitative approach to define the vulnerability of specific type of buildings (reinforced concrete buildings) was done by Mavrouli and Corominas (2010). In Switzerland the official hazard guidelines (OFAT, OFEE, OFEFP 1997) classify the hazard maps according to the return period of a rockfall and its intensity. The latter has two thresholds (30 and $300 \mathrm{~kJ})$ which delimit three intensity classes of a building exposure. Below $30 \mathrm{~kJ}$, only minor damage is expected. Between 30 and $300 \mathrm{~kJ}$ moderate to high damage to houses is expected. Above $300 \mathrm{~kJ}$ threshold total destruction of the house is likely. In this study, similar classification was used to delimit buildings at risk.

This article aims to perform quantitative rockfall hazard modelling and specific risk assessment to buildings of two highly exposed municipalities in the České Švýcarsko National Park in Northwestern Czechia. To do so, it tests regional and local scale rockfall modelling codes (i.e. CONEFALL and RockFall Analyst) to select the best suited approach for urban areas (Corominas et al. 2005). The spatial prediction of rockfall intensities (described by kinetic energy of falling blocks) and frequencies is done using high precision digital elevation model (DEM) derived from the airborne LiDAR data (České Švýcarsko National Park Administration, (C) TU Dresden, IPF).

\section{Study area}

The article focuses on the quantitative hazard and risk analysis of Hřensko and Dolní Žleb municipalities situated along the Elbe River Canyon in the Northwestern Czechia, just next to the border with Germany (Fig. 1). Hřensko is an important tourist destination, called the "gate" to the České Švýcarsko National Park (ČSNP). It is situated on the right river bank, where important international road (n. 62) leads to Germany. Dolní Žleb lies on the left bank of the Elbe River, just few kilometers from Hřensko. Administratively it is part of the Děćn town and it is connected with Germany by a railway.

The origin of rock slopes and the current form of the dissected sandstone relief of the study area results from the long-term dynamic development within a full range of spatial and time scales (e.g. Kalvoda, Zvelebil 1983; Zvelebil 1989; Vařilová, Zvelebil 2007) and affected mainly the sandstones of Late Cretaceous age (Cenoman, Lower and Middle Turonian age), which are part of the Bohemian Cretaceous Basin (e.g. Klein, Opletal, Pražák 1967; Valečka 1989). These massive block sandstones with sub-horizontal stratification are forming plateaus deeply dissected by the Elbe River and its tributaries along which canyons and rock cities developed. The Elbe River cannon developed by repeating episodes of downward erosion during lower and middle Pleistocene 


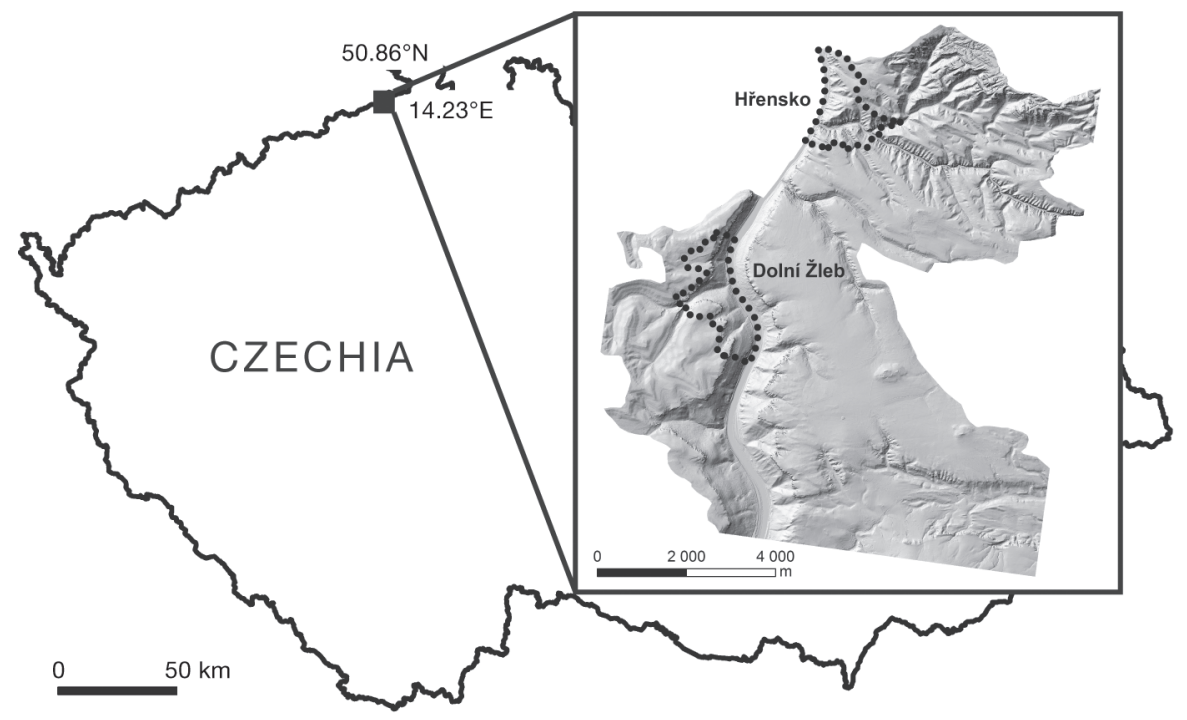

Fig. 1 - Location of the study sites - municipalities Hřensko and Dolní Žleb

due to climatic and partially also tectonic conditions (Kalvoda, Zvelebil 1983) resulting in development of complex river terraces system (Tyráček 2001). The canyon is up to $300 \mathrm{~m}$ deep and in some places also reaches the crystalline basement rocks (e.g. Paleozoic granitic rocks outcrop around the Dolní Žleb municipality). Its slopes are characterized by several levels of cliffs with height from few meters to tens of meters. High and almost vertical rock walls of deep canyons and on rims of plateaus make favourable conditions for geomorphic hazards occurrence. The various types of slope movements together with stream erosion and rock weathering are the main relief development processes within the study area. Relatively common rockfalls, in spite of being an integral part of natural development of sandstone slopes, represent a great danger for local inhabitants and infrastructure, including international transportation corridor throughout the Elbe River Canyon.

An integrated system for effective management of rockfall hazard respecting the nature conservation and enabling reasonable land use is under systematic development in this area. The scientific research and practical applications have been progressively established during the last 30 years (Zvelebil 1995; Zvelebil, Stemberk 2000) mainly within the Elbe River Valley and the Hřensko village.

Knowledge of slope movement kinematics, principal processes participating in strength reduction and stability deterioration, within the rock masses of individual rock objects, as well as of its movement activity is essential for slope safety. The expert based rockfall hazard zoning is being performed in two steps. The first one includes geomorphologic and geological study of relief development and slope conditions resulting into definition of rockfall prone zones. The second step is an inventory of unstable rock objects within the rockfall prone zones using engineering-geological methods. It includes expert assessment of degree of stability of individual rock objects described on four-degree scale 

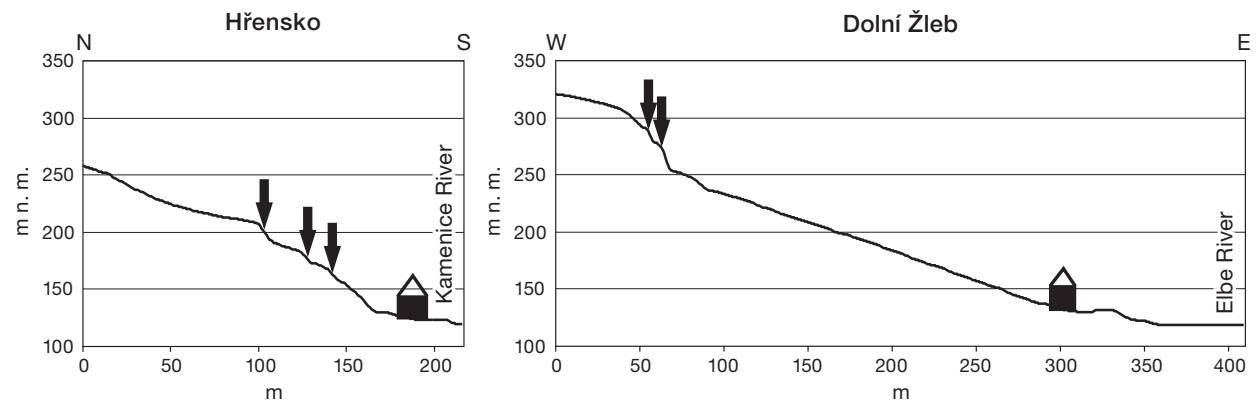

Fig. 2 - Typical slope cross profiles for the Hřensko and Dolní Žleb municipalities constructed over the LiDAR-derived DEM (Správa NP České Švýcarsko, C) TU Dresden, IPF). Arrows shows probable rockfall source areas. The cross profiles locations are shown on Fig. 3.

(Vařilová, Zvelebil 2005; Zvelebil, Vařilová, Paluš 2005). In the long-term used control monitoring of slope movements proved to be a very effective tool as it enabled to detect characteristic features of movement activity in different stages of the process of rockfall preparation.

The two selected municipalities are situated on or just bellow slopes with different typical profiles (Fig. 2). In the case of the Hřensko municipality, the rock cliffs are usually outcropping in the middle or lower part of the slope with several rock faces (Fig. 3) and the slope below them is quite steep $\left(36^{\circ}-50^{\circ}\right)$. It makes the slope generally of convex shape with locally slight concavity in the

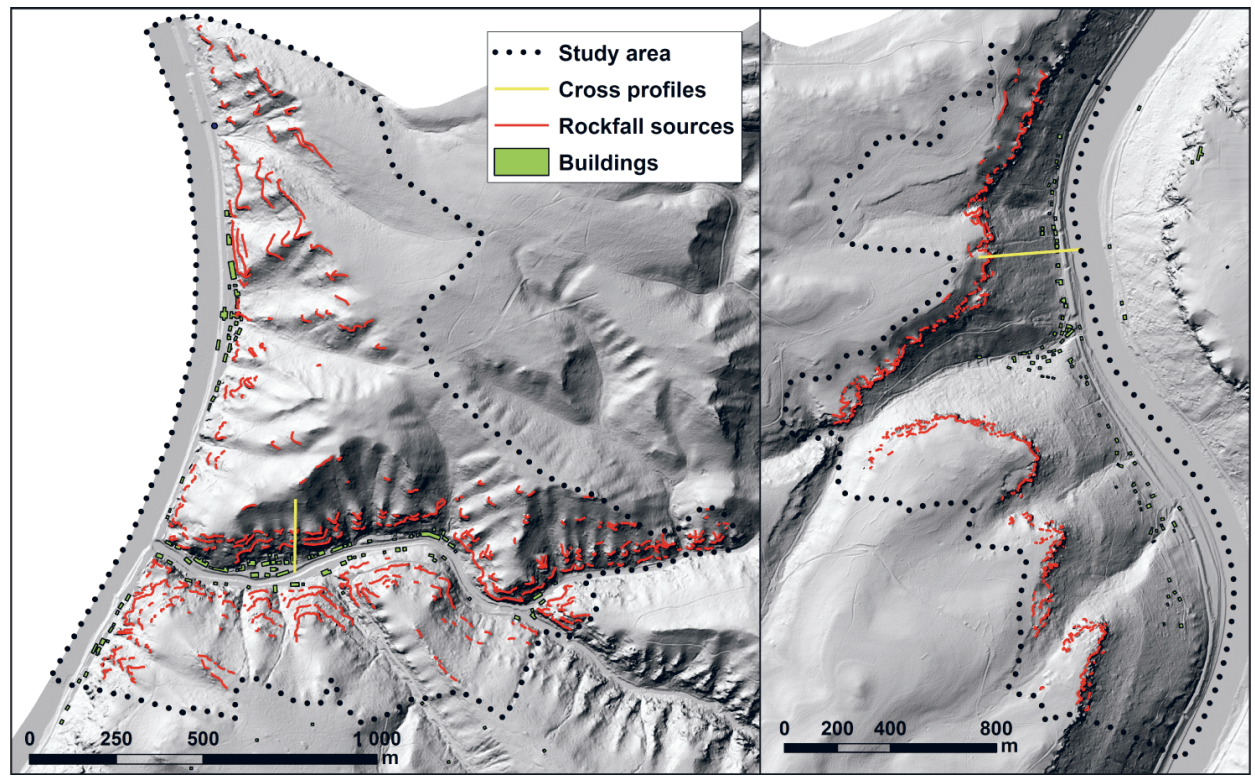

Fig. 3 - Study sites showing shaded relief constructed over the LiDAR-derived DEM (České Švýcarsko National Park Administration, (C) TU Dresden, IPF) with rockfall source areas (left for Hřensko, right for Dolní Žleb). Slope cross profiles from Fig. 2 are also shown. 
upper portion of the slope profile. In the Dolní Žleb case, rock cliffs outcrop on the edge of the plateau in the upper most part of the slope and are followed by slopes with dip between $20^{\circ}-35^{\circ}$ forming predominantly concave slope.

\section{Material and methods}

Two models were used to predict spatial probability of rockfall occurrences and their intensity. For both models the potential rockfall sources were identified on the LiDAR-derived DEM (České Švýcarsko NP Administration, (C) TU Dresden, IPF). The data were acquired during spring 2005 with minimum 1 measurement point per $1 \mathrm{~m}$. For the modelling purposes a DEM with a 5 meter resolution was used. This DEM was used as the basis for the entire spatial analysis.

CONEFALL (Jaboyedoff, Labiouse 2011) modelling code enables regional rockfall runout modelling based on simple Coulomb frictional model using geometric rule called shadow angle or energy line. It assumes that rockfall propagation areas can be modelled by analogy with a block sliding along a slope (Heim 1932). It needs just a DEM, rockfall source areas, and boulder size for the calculation. Rockfall source areas are represented as grid cells and the rockfall runout zones are delimited on the DEM and represented as a grid with various parameters. It is possible to obtain simple boolean runout zone representation, number of contributing source areas, maximum or mean velocity and energy rasters respectively. We used the calculated energy raster to define the intensity of rockfall over modelled runout zones.

The second used modelling code named RockFall Analyst (Lan, Martin, Lim 2007), is an ArcGIS extension for 3D spatially distributed rockfall hazard modelling applicable to both regional and local scale analyses. It models propagation of a rock boulder over DEM using a "lumped mass" approach (Guzzetti et al. 2002 ) to simulate rockfall trajectories. The rockfall source areas are delimited by a point or a line. After the simulation of rockfall trajectories (specifying the parameters of the falling mass and properties of surface) a raster analysis of the results can be performed, resulting in rockfall spatial frequency and hazard rasters. Those can be subsequently used as inputs for the local risk analysis (Lan et al. 2010).

RockFall Analyst uses characteristics of the slope surface affecting friction of the falling block on the slope. Those were determined based on the literature review and basic information about land cover from the official digital topographical database ZABAGED (www.cuzk.cz). The following classes were used - forest, pasture/meadow and orchard.

Available rockfall inventory was used to define volumes of the single blocks found on the accumulation areas of the rockfalls. This does not represent the initial rock block size rather than its fragments which are assumed to move individually along the slope. The typical boulder size used for modelling purposes was $2.5 \mathrm{~m}^{3}$. This corresponds to a rock block weight of $5,000 \mathrm{~kg}$. It was assumed, that a large falling rock breaks apart into smaller blocks of $2.5 \mathrm{~m}^{3}$ size.

Rockfall frequencies for the region of the Northwestern Czechia were calculated using historical data gathered in Špůrek (1967) and Špůrek (1973) which 


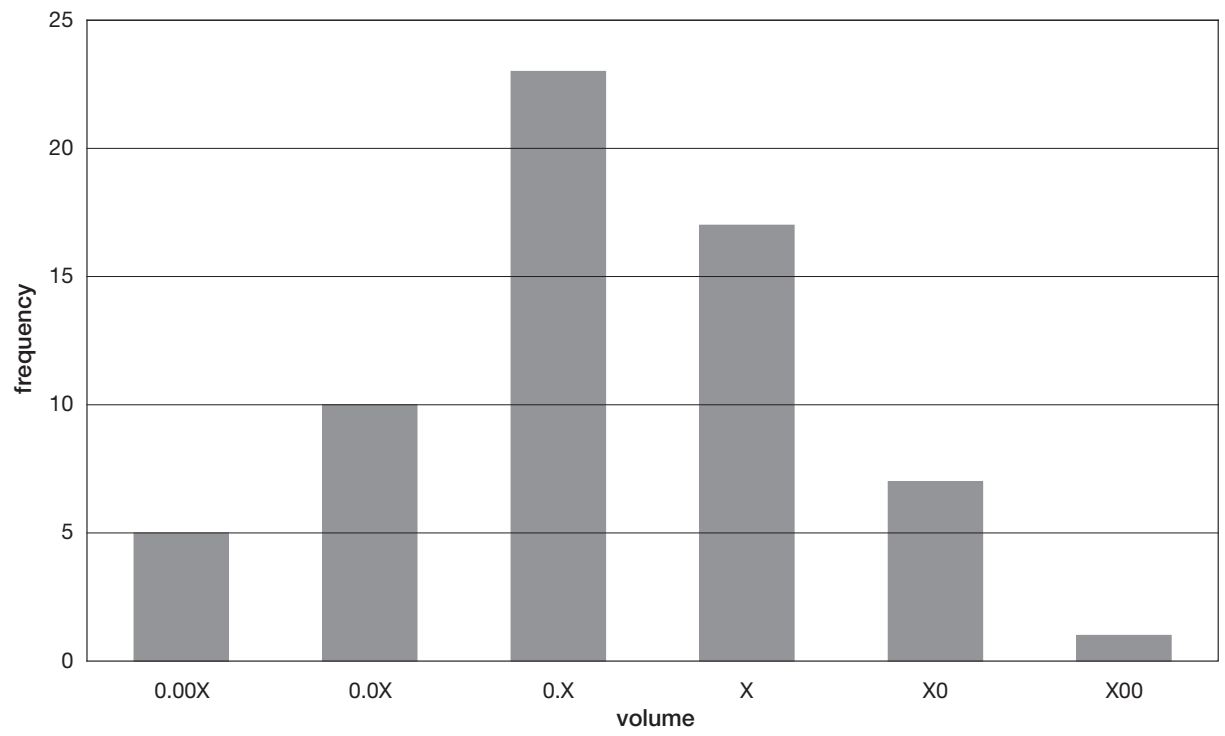

Fig. 4 - Number of rockfalls of specified volume registred between 2001-2010 within the České Švýcarsko National Park (source 2001-2010 rockfall inventory of the ČSNP). Registered volumes vary from $10^{-4} \mathrm{~m}^{3}(0,00 \mathrm{X})$ to $10^{2} \mathrm{~m}^{3}$ (X00).

were summarized by Vařilová and Zvelebil (2007). They concluded for the period $1880-1987$ that rockfalls with volume $\geq 10^{2} \mathrm{~m}^{3}$ occurred with frequency 0.177 per year and rockfalls with volumes $\geq 10^{3} \mathrm{~m}^{3}$ occurred with frequency 0.093 per year.

Recent (2001-2010) rockfall inventory for the České Švýcarsko National Park area captured rockfall frequency of 6.6 per year. Only one case with volume $\geq 10^{2} \mathrm{~m}^{3}$ was recorded. The most frequent rockfalls have volumes between $10^{-2} \mathrm{~m}^{3}$ and $10^{-1} \mathrm{~m}^{3}$ (see Fig. 4). Those relatively low volume events can cause high losses in the most exposed areas (populated areas, traffic corridors or touristic trails) found in the Hrrensko municipality or along the international railway corridor.

More detailed rockfall inventory between years 2003 and 2009 prepared for the Hřensko municipality shows rockfall frequency of 1.14 per year (Table 1). This inventory includes events with volumes $<10^{1} \mathrm{~m}^{3}$ (from $0.002 \mathrm{~m}^{3}$ up to $10 \mathrm{~m}^{3}$ ) and this frequency was used for the hazard calculation. It has to be noted however, that the hazard could be even higher, since preventive remedial works on 20 potentially unstable rock blocks (with volumes from $0.1 \mathrm{~m}^{3}$ to $35 \mathrm{~m}^{3}$ ) were conducted during the period 2003-2009 in the Hřensko municipality.

Historical data show that the seasonal rockfall occurrence peaks in January (and November) which are months with the most frequent rockfall occurrences along the Elbe River during the period of 1901-1950 (Vařilová, Zvelebil 2007). This is mainly due to the fact that occurrence of small rockfalls is connected with regular freeze-thaw periods and heavy rainfall episodes. Wedge-effect of tree roots along with wind-thrown tree fall events contribute significantly to the rockfall origin as well. 
Tab. 1 - Rockfall inventory prepared for the Hřensko village area, 2003-2009

\begin{tabular}{|c|c|c|c|}
\hline Site & Rockfall date & $\begin{array}{l}\text { Total } \\
\text { volume }\end{array}$ & Description \\
\hline Hřensko & April 2003 & $0.002 \mathrm{~m}^{3}$ & $\begin{array}{l}\text { fall of thin rock slab on the hotel's roof, } \\
\text { by wedging of roots }\end{array}$ \\
\hline Hřensko & $\begin{array}{l}\text { January-February } \\
2004\end{array}$ & $1 \mathrm{~m}^{3}$ & $\begin{array}{l}\text { Fall/slide of rock block, by anthropogenic } \\
\text { destabilization }\end{array}$ \\
\hline Hřensko & spring 2004 & $1 \mathrm{~m}^{3}$ & tree fall caused falling of rock blocks \\
\hline Hřensko & August 2006 & $0.65 \mathrm{~m}^{3}$ & $\begin{array}{l}\text { fall of separate block from the rock slope } \\
\text { on the road, by the erosion (after inten- } \\
\text { sive rainfall) }\end{array}$ \\
\hline Hřensko & August 2006 & $4 \mathrm{~m}^{3}$ & $\begin{array}{l}\text { rockfall on parking lott by tree } \\
\text { fall/windthrow during storm }\end{array}$ \\
\hline Hřensko & February 2007 & $1.6 \mathrm{~m}^{3}$ & $\begin{array}{l}\text { toppling and fall of rock slab, by wedg- } \\
\text { ing of roots and water saturation of rock } \\
\text { slope }\end{array}$ \\
\hline Hřensko & September 2007 & $0.08 \mathrm{~m}^{3}$ & $\begin{array}{l}\text { rockfall from cliff face on the pavement, } \\
\text { by erosion of the rock slope }\end{array}$ \\
\hline Hřensko & October 2009 & $9-10 \mathrm{~m}^{3}$ & $\begin{array}{l}\text { outhang fall on to the road, by the water } \\
\text { saturation together with frost affect }\end{array}$ \\
\hline
\end{tabular}

A quantitative calculation of rockfall hazard was undertaken by applying the following formula:

$$
H_{R F}=R F \times P_{S} \times I
$$

where $H_{R F}$ is rockfall hazard for the specified boulder size, $R F$ is rockfall frequency, $P_{S}$ stands for spatial probability of an area exposed to rockfall and $I$ is rockfall intensity (in $\mathrm{kJ})$. A scenario with a rock block of $2.5 \mathrm{~m}^{3}(5,000 \mathrm{~kg})$ was calculated. This block was the largest found on past rockfall accumulations. The scenario was calculated for both of the modelling codes.

The resulting hazard areas delimited by the model were classified into three classes, according to intensities of possible rockfalls. The classes were delimited according to a Swiss methodology (OFAT, OFEE, OFEFP 1997) used in rockfall hazard assessment. The lowest hazard class covers area where potential rockfall can reach intensity of less than $30 \mathrm{~kJ}$. Medium hazard class covers areas between 30 and $300 \mathrm{~kJ}$ rockfall intensities and the high hazard class comprises areas of rockfall intensities higher than $300 \mathrm{~kJ}$.

Calculation of risk (i.e. probability of adverse effect due to rockfall hazard Blahůt, Klimeš 2011) was performed on buildings in the both study areas. For this specific risk to buildings, vulnerability values were derived from the Swiss methodology (OFAT, OFEE, OFEFP 1997). In the low risk class only light damage to houses is possible, as the impact force of the falling block does not exceed $30 \mathrm{~kJ}$. The medium risk class is characterized by possible moderate to high damage with boulder impact forces between 30 and $300 \mathrm{~kJ}$. In the high risk class, buildings are likely to be totally destroyed, as the impact forces exceed $300 \mathrm{~kJ}$. The monetary value of the buildings was not taken into account, so as a consequence only the probable state of the buildings after rockfall was the result of the risk analysis. 


\section{Results and discussion}

\subsection{Hazard analysis}

Results from the quantitative hazard analysis are shown on Figure 5. For both study areas and both modelling codes past rockfall runout zones were used for calibration. The CONEFALL model was calculated with $35^{\circ}$ shadow

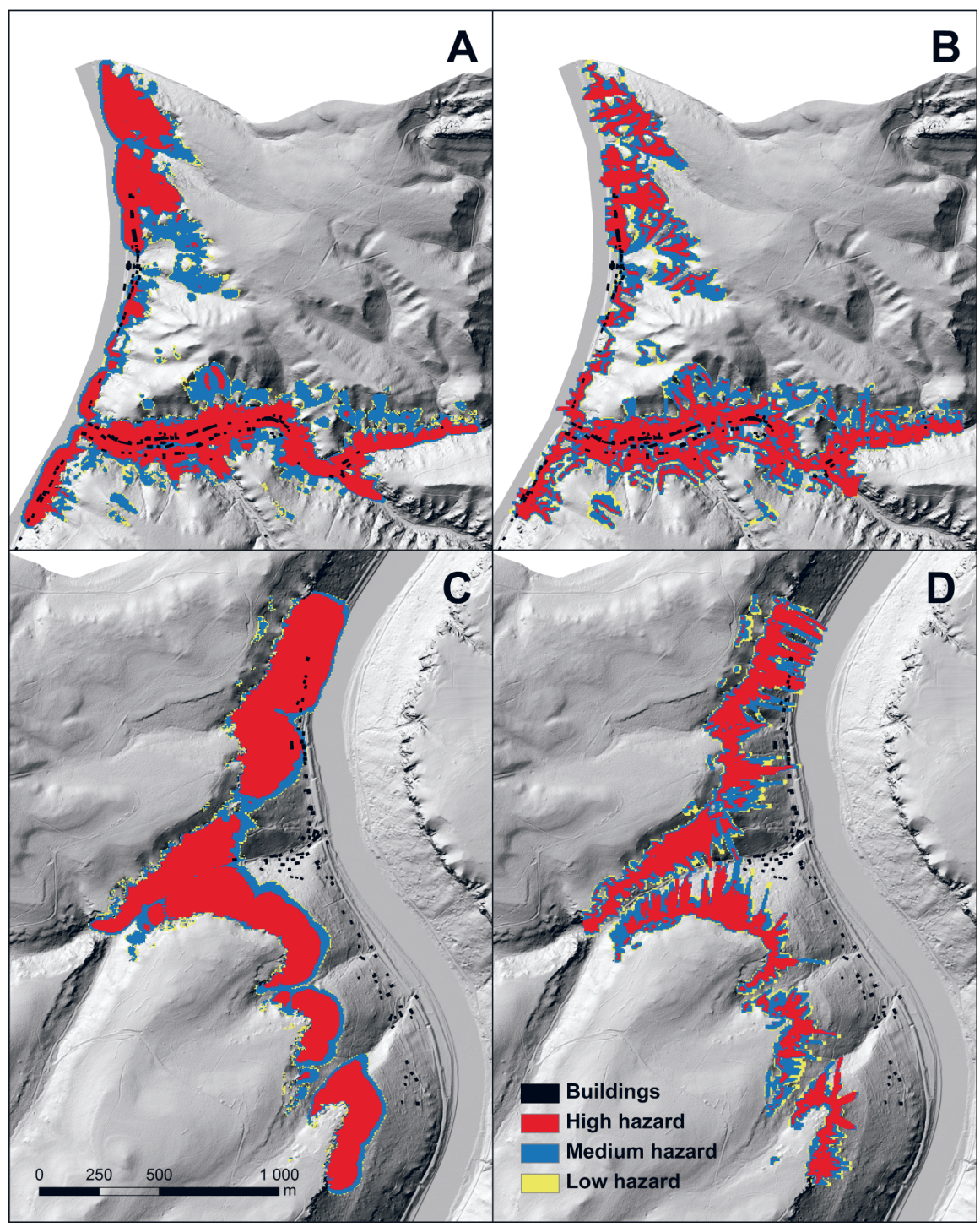

Fig. 5 - Rockfall hazard maps for the different study sites and models applied. A: Hřensko CONEFALL model, B: Hřensko - RockFall Analyst, C: Dolní Žleb - CONEFALL model, D: Dolní Žleb - RockFall Analyst. 
angle, while the RockFall Analyst used for majority of the area (forests) the restitution coefficient of 0.2 , tangential restitution coefficient 0.5 , and friction angle of $30^{\circ}$. As it can be seen in both study areas, the CONEFALL model shows different shape of the runout zones, compared to the RockFall Analyst. This is caused by the fact, that CONEFALL code models the rockfall like sliding over DEM surface, while RockFall Analyst models propagation of individual blocks, including trajectories, showing bouncing and free fall. The raster hazard maps showing maximum energies of falling block were prepared and classified according to the Swiss methodology (OFAT, OFEE, OFEFP 1997) into three classes showing high, medium and low hazard zones.

By comparing the maps in the Hřensko area, CONEFALL delimits a total of $768,875 \mathrm{~m}^{2}$ of hazardous area with $49.8 \%$ in the high hazard class, $41.5 \%$ in medium hazard class and the remaining $8.7 \%$ in low hazard class. The RockFall Analyst delimits as hazardous $822,375 \mathrm{~m}^{2}$, with $45.9 \%$ in the high hazard class, $43.5 \%$ in the medium hazard class and $10.6 \%$ belongs to the low hazard class with maximum impact energies lower than $30 \mathrm{~kJ}$.

In the Dolní Žleb area, CONEFALL delimits 722,050 $\mathrm{m}^{2}$ as hazardous area, with $72.7 \%$ in the high hazard zone, $21.9 \%$ in medium hazard zone and only $5.4 \%$ in the low hazard zone. The RockFall Analyst predicts as hazardous $630,175 \mathrm{~m}^{2}$, with $52.1 \%$ in high hazard zone, $36.9 \%$ in medium hazard zone and $11 \%$ in the low hazard zone.

In case of Hřensko study area, the applied model does not show large differences, neither in the total area predicted as hazardous, nor in the share of the hazard classes. Much larger differences exist in case of the Dolní Žleb study site. There the difference can be caused by different profile of the slopes, compared to Hřensko (Fig. 2). In Hřensko the slopes are very steep in their whole profile and the resulting effect is that the propagation zones and hazardous areas are restricted to the entire narrow valleys. In Dolní Žleb, steep slopes are present mostly in the upper part, while the lower parts are covered by dense forests. This causes that the RockFall Analyst, which uses properties of surface for the calculation of the runout zones, delimits smaller hazard area than CONEFALL, which does not take into account this parameter.

It can be clearly seen from the Figure 5, that RockFall Analyst more precisely delimits the rockfall runout zones as it is based on calculation of rockfall trajectories. This is, together with the above discussed incorporation of surface properties, the main advantage of this modelling code, compared to CONEFALL. As a consequence, the outputs of the RockFall Analyst modelling are better applicable for consequent risk analysis. However advantage of CONEFALL remains in the fast data processing with no need to incorporate surface properties for a preliminary estimation of the rockfall runout zones.

\subsection{Risk analysis}

From a total of 113 buildings in the Hřensko area, 95 are at risk from rockfalls in the CONEFALL model. Most of them are at risk of total destruction (82), nine of them are at risk of being moderately to highly damaged and four can suffer light damage. The RockFall Analyst delimited 89 buildings being at 


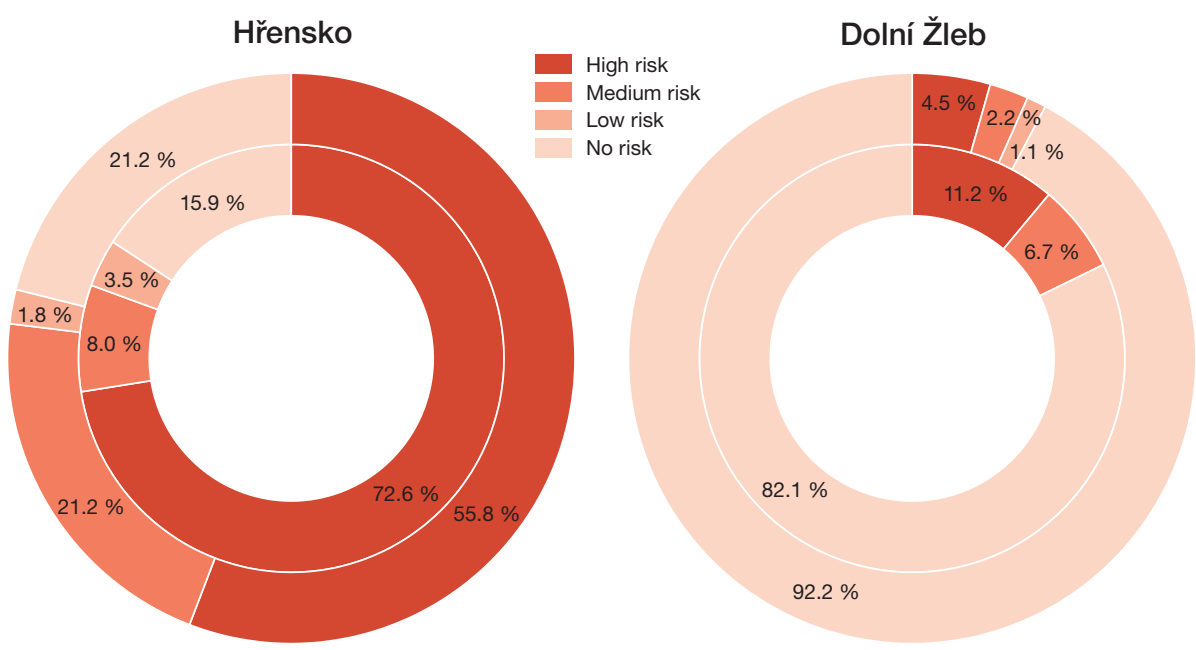

Fig. 6 - Share of buildings at risk from rockfall hazard in Hřensko and Dolní Žleb for the respective modelling codes. Inner circle for CONEFALL and outer circle for RockFall Analyst.

risk, 63 of them at risk of total destruction, 24 at risk of moderate-high damage and two at risk of light damage.

In the Dolní Žleb area, 89 buildings are present. The CONEFALL model delimits only 16 of them being at risk. Six buildings are at risk of moderatehigh damage, 10 at risk of total destruction. The RockFall Analyst delimits only seven buildings being at risk from rockfalls. One building can suffer light damage, two buildings can be moderately to highly damaged and four buildings are at risk of being totally destroyed.

From Figure 6 it can be seen the share of building risk classes for the respective models and study areas. Most of the buildings are at risk of total damage in the Hřensko area. This is mostly caused by the local geomorphology, which limits the urbanization to the highly hazardous narrow valley bottoms. On the contrary, lower slopes of Dolní Žleb allowed building directly on the slopes farther from the dangerous rock cliffs. This permitted to allocate the buildings in safer conditions than in the Hřensko village. As a consequence, buildings in Dolní Žleb are at much lower risk than in Hřensko. It has to be noted however, that in both cases and both modelling results, the majority of the affected houses is likely to be totally destroyed due to very high impact energies of falling rocks. At the same time, the scenario based on $2.5 \mathrm{~m}^{3}$ falling blocks could be conservative, as it is likely that some of the blocks will further disintegrate during falling and the impact energies will dissipate. For that reason, more tests are needed, incorporating different volumes of falling blocks.

\subsection{Limitations and uncertainties}

There are several limitations and uncertainties, which have already been discussed. However, some general limitations and recommendations can be 
summed. According to Bell and Glade (2004) the resulting risk values indicate a considerable uncertainty due to the uncertainties inherent in each input factor of risk analysis. Main limitation of susceptibility and hazard analysis is usually connected with the spatial resolution and reliability of the inputs. This uncertainty is highly reduced by using high precision LiDAR elevation data, which play a decisive role in spatial prediction of rockfall runouts (Lan et al. 2010). There is high uncertainty connected with the definition of starting zones of the rockfalls. Not all mapped sandstone cliffs are equally susceptible for the rockfall occurrence. This uncertainty may be overcome by using results of detailed field expert mapping and ranking of the unstable rock blocks. It was performed only within the Hřensko area (Šebesta et al. 2000; Zvelebil, Vařilová, Paluš 2005; Zvelebil 2007). Other uncertainty is connected with the estimation of rockfall frequencies, which is based on limited historical catalogues. The high magnitude events are captured in sufficiently long time period (1880-1987), but lack spatial resolution and we need to assume that huge amount of small events $\left(\geq 10^{1} \mathrm{~m}^{3}\right)$ is missing in this dataset. On the other hand, the rockfall inventory performed for the period 2003-2009 captured all events, which occurred within the České Švýcarsko National Park, but its reliability is limited due to short time span. Application of regional (CONEFALL) and slope scale (RockFall Analyst) rockfall modelling codes provided us two different risk zonings of the studied municipalities. End users (e.g. local administration) does not have expertise to decide which is more appropriate for their use and presenting them with two different risk zoning may cause confusion. We suggest that results of RockFall Analyst should be used for the regional scale development planning purposes as the model considers more closely the slope morphology and characteristics.

\section{Conclusions}

In the presented manuscript the rockfall hazard and risk was analyzed within the selected municipalities of Northwestern Czechia. Two different models showed highly similar results of the rockfall hazard assessment in the study area with steep $\left(36^{\circ}-50^{\circ}\right)$ and relatively short (up to $200 \mathrm{~m}$ of horizontal distance) slopes covered with equally distributed forest (Hřensko town). On the other hand, resulting rockfall hazard zoning of the study area (Dolní Žleb) with comparable lower slope dip $\left(20^{\circ}-35^{\circ}\right)$, slopes with $350 \mathrm{~m}$ of horizontal distance and presence of dense forest in the lower part of the slope was significantly different. The CONEFALL software delimited larger area as being hazardous and the share of the high hazard zone was $20 \%$ larger than the one defined by RockFall Analyst, which identified low rockfall hazard on two times bigger portion of the studied area than the CONEFALL software. The differences are being caused by more complex input information used in the RockFall Analyst representing local slope and energy loss coefficients of the falling boulders as well as the fact that CONEFALL calculations simplifies the modelled rockfall considering sliding of rock blocks rather than its falling and bouncing. We can conclude that the RockFall Analyst maps the rockfall hazard more realistically in a variety of natural conditions especially within the studied region. 
Risk was analyzed for the buildings exposed on the hazardous areas with respect to prospective degree of damage to buildings caused by rockfalls. For each building the potential rockfall impact forces were extracted and prospective damage was assessed. The risk analysis based on the CONEFALL model were in both study areas more conservative assigning higher number of affected buildings as well as buildings predicted as being totally destroyed by the rockfalls. This finding further stress the model differences as the risk assessment directly depends on rockfall impact forces calculated by the models. Also in this case we suggest that the RockFall Analyst provides more realistic input data for the risk assessment. Irrespective of the applied rockfall modelling software, calculated risk to buildings differed significantly in the two study areas. Higher risk (shown by high portion of more severely affected buildings) was determined in the Hřensko municipality due to steeper and shorter slopes, which produce rockfalls with higher impact forces.

Comparison of two different rockfall hazard models over the same study areas with comparable input data allows more precisely to define conditions under which they are capable of producing reliable outputs. It favours more complex RockFall Analyst software over the more general approach used in the CONEFALL model. Reliability of the rockfall hazard assessment was in both cases significantly improved by using high resolution topographic data and application of detailed rockfall inventory. However, for a proper risk assessment more information considering vulnerability and value of the exposed buildings is needed.

\section{References:}

ALMEIDA, J.A., KULLBERG, J.C. (2011): Rockfall hazard and risk analysis for Monte da Lua, Sintra, Portugal. Natural Hazards, 58, pp. 289-310.

BELL, R., GLADE, T. (2004): Quantitative risk analysis for landslides - examples from Bíldudalur, NW Iceland. Natural Hazards and Earth System Sciences, 4, pp. 117-131.

BIGOT, CH., DORREN, L.K.A., BERGER, F. (2009): Quantifying the protective function of a forest against rockfall for past, present and future scenarios using two modeling approaches. Natural Hazards, 49, pp. 99-111.

BLAHU゚T, J., KLIMEŠ, J. (2011): Příspěvek k české terminologii ve studiu rizik ze svahových deformací. Geografie, 116, No. 1, pp. 79-90.

CARDINALI, M., REICHENBACH, P., GUZZETTI, F., ARDIZZONE, F., ANTONINI, G., GALLI, M., CACCIANO, M., CASTELLANI, M., SALVATI, P. (2002): A geomorphological approach to the estimation of landslide hazards and risks in Umbria, Central Italy. Natural Hazards and Earth System Sciences, 2, pp. 57-72.

COROMINAS, J., RAMON, C., MOYA, J., VILAPLANA, J.M., ALTIMIR, J., AMIGÓ, J. (2005): Quantitative assessment of the residual risk in a rockfall protected area. Landslides, 2, pp. 343-357.

GUZZETTI, F., CROSTA, G.B., DETTI, R., AGLIARDI, F. (2002): STONE: a computer program for the three-dimensional simulation of rock-falls. Computers \& Geosciences, 28, pp. 1079-1093.

HEIM, A. (1932): Bergsturz und Menschenleben, Fretz und Wasmuth. Zurich, 218 pp.

KATZ, O., REICHENBACH, P., GUZZETTI, F. (2011): Rock fall hazard along the railway corridor to Jerusalem, Israel, in the Soreq and Refaim valleys. Natural Hazards, 56, pp. 649-665.

KLIMEŠ, J., VILÍMEK, V., OMELKA, M. (2009): Implications of geomorphological research for recent and prehistoric avalanches and related hazards at Huascaran, Peru. Natural Hazards, 50, pp. 193-209. 
LAN, H., MARTIN, C.D., LIM, C.H. (2007): RockFall analyst: A GIS extension for threedimensional and spatially distributed rockfall hazard modeling. Computers \& Geosciences, 33, No. 2, pp. 262-279.

LAN, H., MARTIN, C.D., ZHOU, C., LIM, C.H. (2010): Rockfall hazard analysis using LiDAR and spatial modeling. Geomorphology, 118, pp. 213-223.

MAVROULI, O., COROMINAS, J. (2010): Vulnerability of simple reinforced concrete buildings to damage by rockfalls. Landslides, 7, pp. 169-180.

JABOYEDOFF, M., LABIOUSE, V. (2011): Technical Note: Preliminary estimation of rockfall runout zones. Natural Hazards and Earth System Sciences, 11, pp. 819-828.

KALVODA, J., ZVELEBIL, J. (1983): Dynamika a typy porušování svahů při vývoji údolí Labe v Děčínské vrchovině. Acta Montana, Praha, 63, pp. 5-73.

KLEIN, V., OPLETAL, M., PRAŽÁK, J. (1967): Vysvětlující text k základní geologické mapě 1:25000, list M 33-41-A-c Königstein and M 33-41-A-d Hřensko. UUG, Geofond, Praha, $22 \mathrm{pp}$.

OFAT, OFEE, OFEFP (1997): Recommandations 1997 - Prise en compte des dangers dus aux crues dans le cadre des acivités de l'aménagement du territoire. Bern, OFAT/OFEE/ OFEFP, $32 \mathrm{pp}$.

STURZENEGGER, M., SARTORI, M., JABOYEDOFF, M., STEAD, D. (2007): Regional deterministic characterization of fracture networks and its application to GIS-based rock fall risk assessment. Engineering Geology, 94, pp. 201-214.

ŠEBESTA, J. et al. (2000): Nebezpečí svahových pohybů v údolí Labe na okrese Děčín, part F. MS ČGÚ, Praha, 26 pp.

ŠPU゚REK, M. (1967): Historická analýza působení sesuvného faktoru v Českém masivu. CSc. thesis, Academy of Science of the Czech Republic, 105 pp.

ŠPŮREK, M. (1973): Retrospection and Prognosis of Landslide Calamities. Mineral. Geol., 19, No. 2, pp. 119-134.

TYRÁČEK, J. (2001): Upper Cenozoic fluvial history of the Bohemian Massif. Quaternary International, 79, pp. 37-53.

VALEČKA, J. (1989): Sedimentology, stratigraphy and cyclicity of the Jizera Formation (Middle-Upper Turonian) in the Děčín area (N. Bohemia). Věstník Ústředního ústavu geologického, 64, No. 2, pp. 77-90.

VARIILOVÁ, Z., ZVELEBIL, J. (2005): Sandstone Relief Geohazards and their Mitigation: Rock Fall Risk Management in the Bohemian Switzerland NP, Czech Republic. FerrantiaTravaux scientifiques de Musee national d'historie naurelle, Luxembourgh, 44, pp. 51-56.

VAŘILOVÁ, Z., ZVELEBIL, J. (2007): Catastrophic and episodic events in sandstone landscapes: slope movements and weathering. - In: Härtel, H., Cílek, V., Herben, T., Jackson A., Williams R. (eds.): Sandstone Landscapes, Academia, Praha, pp. 115-128.

WAGNER, A., OLIVER, R., LEITE, E. (1988): Rock and debris slide risk maps applied to low-volume roads in Nepal. Transportation Research Record 1106. TRB. National Research Council,Washington, D.C., pp. 255-267.

ZVELEBIL, J., VARILOVÁ Z., PALUŠ M. (2005): Tools for rock fall risk integrated management in sandstone landscape of the Bohemian Switzerland National Park, Czech Republic (M121). In: Sassa, K., Fukuoka, H., Wang, F., Wang, G. (eds.): Landslides - Risk Analysis and Sustainable Disaster Management. Springer, pp. 119-126.

ZVELEBIL, J. (1989): Inženýrskogeologické aspekty vývoje skalních svahů v Děčínské vrchovině. CSc. Thesis, UGG ČSAV, Praha, 282 pp.

ZVELEBIL, J. (1995): Determination of characteristic features of slope movements presentday activity by monitoring in thick-bedded sandstones of the Bohemian Cretaceous Basin. Acta Universitatis Carolinae, Geographica, 30, Suppl., pp. 79-113.

ZVELEBIL, J. (2007): Rajonizace rizik ohrožení skalními říceními ze skalních svahů na území obce Hřensko. MS OÚ Hřensko, archiv ČGS Praha, 9 pp.

ZVELEBIL, J., STEMBERK, J. (2000): Slope Monitoring in Nature-Friendly of Rock Fall Danger from Sandstone Rock Walls in Děčín Highland, NW Bohemia. Proc VIII Int. Symp. on Landslides, Cardiff, 67 pp. 


\title{
KVANTITATIVNÍ HODNOCENÍ OHROŽENÍ A RIZIKA ZE SKALNÍHO ŘÍCENÍ VE VYBRANÝCH OBCÍCH NÁRODNÍHO PARKU ČESKÉ ŠVÝCARSKO, SEVEROZÁPADNÍ ČESKO
}

\begin{abstract}
Skalní řícení představují velmi rychlý pohyb různě velkých bloků hornin po svahu, jehož část se děje volným pádem. Jejich objem kolísá od několika krychlových centimetrů až po tisíce krychlových metrů. Díky vysokým rychlostem mohou i velmi malé objemy padající horniny zpo̊sobit velké škody. Je proto důležité vyhodnotit co nejobjektivněji míry ohrožení a rizika, které způsobují skalní řícení v oblastech s jejich vysokým výskytem. Oblastí s největší frekvencí skalních řícení, kde jsou zároveň hustě zastoupeny ohrožené objekty, je údolí Labe v Národním parku České Švýcarsko procházející druhohorními pískovcovými sedimenty. $\mathrm{Z}$ těchto důvodů byla provedena analýza ohrožení a rizika ze skalních řícení pro okolí obcí Hřensko a Dolní Žleb v severovýchodních Čechách. K tomuto účelu byly použity modelovací programy CONEFALL a RockFall Analyst. První představuje regionální model založený na Coulombově kritériu smykové pevnosti a předpokladu, že skalní ŕícení je možné zjednodušit jako sesouvání po rovinné ploše. Naopak RockFall Analyst modeluje pohyb skalního bloku (volný pád a odraz od svahu) a ztrátu jeho energie v důsledku tření při jednotlivých dopadech. Výsledky obou programů je možné použít pro vyhodnocení prostorové pravděpodobnosti výskytu a intenzity skalních řícení. Při modelování bylo použito podrobného digitálního modelu území vytvořeného na základě dat LiDAR (Správa NP České Švýcarsko, C) TU Dresden, IPF). Tento model byl také použit pro identifikaci možných zdrojových oblastí skalních řícení. Velikost padajících balvanů byla určena na základě analýzy inventarizací skalních řícení pro Národní park Českosaské Švýcarsko a obec Hřensko. Tato data posloužila také pro stanovení frekvence výskytu skalních řícení. Charakteristika povrchu svahu, která je nutnou podmínkou pro výpočet ohrožení programem RockFall Analyst, byla odvozena z dat ZABAGED. Riziko ze skalního řícení bylo hodnoceno pouze pro budovy, které byly získány z topografických data ZABAGED. Intenzita skalního řícení byla klasifikována na základě švýcarské metodiky OFAT, OFEE, OFEFP (1997) - nízká intenzita 0-30kJ; střední intenzita 30-300 kJ; vysoká intenzita nad 300 kJ.

Výsledky hodnocení ohrožení a rizika ze skalních řícení ukázaly na rozdíly v metodice jejich stanovení u obou použitých modelovacích programů. V případě obce Hřensko identifikovaly oba programy přibližně stejnou plochu ohroženou skalním řícením. I zastoupení jednotlivých tříd ohrožení bylo velmi podobné. Nicméně ve studované oblasti Dolní Žleb byl výsledek obou programů odlišný. Lišila se jak celková plocha území ohroženého skalním řícením (ta byla o skoro $100000 \mathrm{~m}^{2}$ větší v př́ípadě výsledků programu CONEFALL), tak její zařazení do jednotlivých tříd ohrožení. V tomto př́ípadě zařadil program CONEFALL o $20 \%$ více území do nejvyšší třídy v porovnání s výsledky programu RockFall Analyst. Svahy v okolí obce Hřensko jsou relativně strmé (36-50) a krátké (do 200 m horizontální délky). Podmínky vzniku skalních řícení tak byly správně vystiženy oběma použitími modely. V případě obce Dolní Žleb jsou svahy mnohem méně strmé $\left(20-35^{\circ}\right)$ a delší (cca 350 m horizontální vzdálenosti). Zjednodušený přistup $\mathrm{k}$ popisu skalního bloku pohybujícího se po svahu v případě modelu programu CONEFALL se ukázal jako méně vhodný a více konzervativní. Na rozdíl od něj program RockFall Analyst lépe zohlednil vliv sklonu svahů na pohyb bloků a také efekt ztráty energie $\mathrm{v}$ důsledku přítomnosti hustého lesa, který měl větší vliv na balvany pohybující se po méně strmých svazích. Předpokládáme, že výsledky programu RockFall Analyst lépe vystihují nebezpečí skalních řícení v této studované oblasti.

Rozdíly v hodnocení rizika byly způsobeny jednak výše popsanými odlišnostmi v hodnocení ohrožení ze skalních řícení a jednak odlišnými sklonovými poměry v obou studovaných oblastech. Ukázalo se, že většina domů v obci Hřensko spadá do kategorie vysokého nebo středního rizika. Naopak domů v těchto kategoriích v lokalitě Dolní Žleb je relativně málo. To je zpo̊sobeno vyšší kinetickou energií padajících bloků v okolí Hřenska, kde je tak větší pravděpodobnost, že dům bude zasažen balvanem, který je schopen způsobit zásadní škody. Je velmi pravděpodobné, že domy v nejvyšší kategorii rizika by byly z větší části skalním řícením zničeny.
\end{abstract}


Obr. 1 - Lokalizace studovaných oblastí - obce Hřensko a Dolní Žleb.

Obr. 2 - Typické podélné profily svahy v lokalitách Hřensko a Dolní Žleb vytvořený z digitálního modelu reliéfu odvozeného z měření LiDAR (Správa NP České Švýcarsko, (C) TU Dresden, IPF). Šipky ukazují pravděpodobné zdrojové oblasti skalních řícení. Umístění podélných profilů ukazuje obr. 3 .

Obr. 3 - Stínovaný reliéf studovaných oblastí byl vytvořen s použítím dat LiDAR (Správa NP České Švýcarsko, (C) TU Dresden, IPF). Vyznačeny jsou potenciální zdrojové oblasti skalních řícení (vlevo studovaná oblast Hřensko, vpravo Dolní Žleb), stejně jako podélné profily z obr. 2.

Obr. 4 -Cetnost skalních řícení podle kubatury spadlých bloků zaznamenaných v letech 2001-2010 v Národním parku Českosaské Svýcarsko. Objemy jsou v rozmezí $10^{-4} \mathrm{~m}^{3}$ $(0,00 \mathrm{X})$ až $10^{2} \mathrm{~m}^{3}(\mathrm{X} 00)$.

Obr. 5 - Mapy ohrožení ze skalních řícení pro jednotlivé studované oblasti a použité modely. A: Hřensko - program CONEFALL, B: Hřensko - RockFall Analyst, C: Dolní Žleb program CONEFALL, D: Dolní Žleb - RockFall Analyst.

Obr. 6 -Podíl budov v jednotlivých třídách rizika z ohrožení skalním řícením v Hřensku a Dolním Žlebu. Vnitřní kruh pro program CONEFALL, vnější kruh pro program RockFall Analyst.

Authors' affiliation: J. Blahůt and J. Klimeš: Institute of Rock Structure and Mechanics, Academy of Sciences of the Czech Republic, V Holešovičkách 41, Prague, Czechia; e-mail: blahut@irsm.cas.cz.Z. Vařilová: Museum of the Ústí nad Labem town, Masarykova 1000/3, Ústí nad Labem, Czechia.

Initial submission, 31 May 2012; final acceptance 7 July 2013.

\section{Please cite this article as:}

BLAHU゚T, J., KLIMEŠ, J., VAŘILOVÁ, Z. (2013): Quantitative rockfall hazard and risk analysis in selected municipalities of the České Śvýcarsko National Park, northwestern Czechia. Geografie, 118, No. 3, pp. 205-220. 